\title{
A Critical Appraisal of Off-land Structures: A Futuristic Perspective
}

\author{
Gaurav Sarswat, Mohammad Arif Kamal* \\ Department of Architecture, Aligarh Muslim University, India \\ *Corresponding Author: architectarif@gmail.com
}

Copyright (C) 2014 Horizon Research Publishing All rights reserved.

\begin{abstract}
There will be crisis of land leading to the need of development of the infrastructure for residential, commercial, industrial \& agricultural use due to exponential growth in population, current and projected. The metropolitan cities are developing at a very high rate and the expecting rise in population is putting pressure on these cities to grow further by expanding their boundaries continuously. But in the case of cities like Mumbai, Chennai and international coastal cities, the sea is behaves like a boundary for urban settlement, resisting its further expansion. This situation has produced challenges for urban planners to deal with lack of space and demand for basic amenities. In such condition coastal metropolitans, oceans can be used to develop the floating form of satellite towns, urban pockets \& structures as a coastal expansion of city boundaries due to the enormous flexibility and limitless possibilities which water offers. The objective of this paper is to highlight the possibilities of off land development on water. It begins with the review of need of floating structures and their scope towards development \& growth of cities. It includes a brief history and case studies related
\end{abstract}

to evolution and development of floating structures from our past to present and finally the authors presents different types of design methodology with which these ideas can be implemented.

Keywords Population Explosion, Land Shortage, Off-land Structures, Coastal Metropolitan

\section{Introduction}

The earth contains all kind of resources to sustain life and need of all human beings, plants \& animals. But it is greed of humans which is exploiting these resources to fulfill their endless greed. According to the medium variant of the 2010 Revision of World Population Prospects as shown in Figure 1 the world population is expected to increase from 6.9 billion in mid-2011 to 9.3 billion in 2050 and to reach 10.1 billion by 2100 . [1].

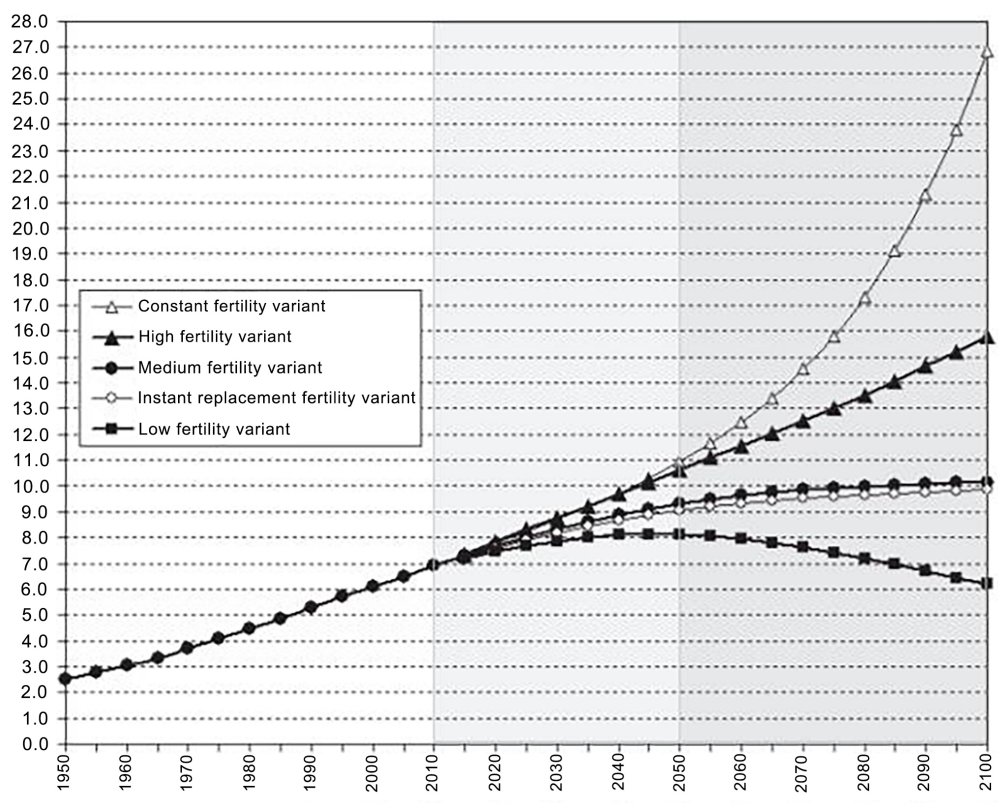

Figure 1. The total population of the world by projection variant (Source:www.un.org) 


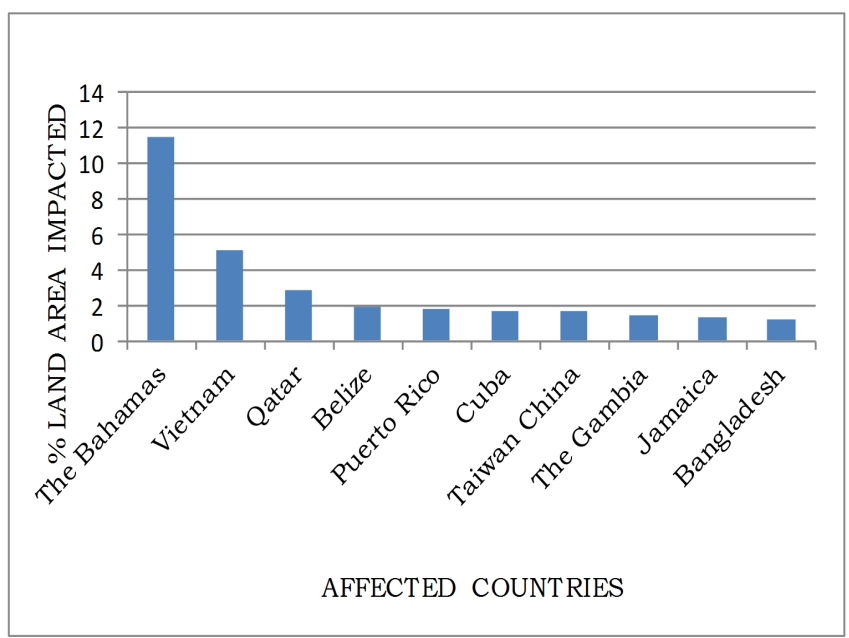

Figure 2. The percentage land area of the most impacted countries (Source: www.ibtimes.com)

The majority of the population growth in upcoming years will occur in urban areas of developing countries. The basic and the most important resource for the survival of human being is the land. For a long term perspective for our future land will become a major issue. According to US Geological survey, presently we have land area of about $148,300,000$ sq. $\mathrm{km}$, as about $29 \%$ of total surface area of earth, from which almost $50 \%$ is unsuitable for habitation \& agricultural purpose due to poles, deserts $\&$ hard rocks $\&$ mountains. the remaining $71 \%$ surface area of planet earth is occupied by water [2], \& from this total quantity, $96.54 \%$ founds in Oceans, Seas, \& Bays [3], which is about 68.54 of total surface area According to forecasts of the IPCC, the ocean level will rise from 20 to $90 \mathrm{~cm}$ during the $21 \mathrm{st}$ century (versus $10 \mathrm{~cm}$ in the 20th century) [4]. According to the research, published in the Proceedings of the National Academy of Sciences, a global mean temperature elevation of $1^{\circ} \mathrm{C}$ will lead to rise of 2 meter in mean sea level [5]. Increase of $1 \mathrm{~m}$ would bring out the world to loose of approximately $0.31 \%$ of ground \& $1,30 \%$ of GDP. Further effect of this rise of $1 \mathrm{M}$ in MSL is given in Table 1 and Figure 2 shows the most impacted countries according to land area. [6]. The objective of this paper is to study the possibilities of off-land structures on water. It begins with the need of floating structures and their scope of contribution towards development and growth of cities. It includes a brief history and case studies related to evolution and development of floating structures and finally the authors conclude with the different design methods for off-land structures.

Therefore we need to find out proper solutions for upcoming problems due to population explosion, increase in sea level \& limited amount of available land. For agricultural and industrial purpose we have very limited usable land area (approximate $12 \%$ of earth) so development of off land structure is the option where we can look forward for solution of our problems related to housing, employment and infrastructure and investment. This development of 'off land' structure in sea will definitely reduce the load on the shoulders of our mother earth.

The development of such kind of structure will be a new concept initially in present time, but within a very short span of time in future this will become the necessity and trend.

\section{Research Methodology}

In this paper qualitative research methodology is used. A critical analysis of the possibilities of off-land structures on water has been done. The paper also discusses the need of floating structures and their scope for the growth of urban centers. Further the paper also validates the study by three case studies of off-land structures namely The Greenstar and the Floating Golf Course at Maldives and a hypothetical study of a Floating Ecopolis. An appraisal of the different design methods and design considerations of off-land structures has also been done.

Table 1. Summary of world regional impacts due to rise in sea level (Source: www.openknowledge.worldbank.org)

\begin{tabular}{|c|c|c|c|c|c|c|}
\hline Indicators & World & $\begin{array}{c}\text { Latin America \& } \\
\text { Caribbean }\end{array}$ & $\begin{array}{c}\text { Middle east } \\
\& \text { North Africa }\end{array}$ & $\begin{array}{c}\text { Sub Saharan } \\
\text { Africa }\end{array}$ & East Asia & South Asia \\
\hline & \multicolumn{6}{|c|}{$1 \mathrm{M} \mathrm{SLR}$} \\
\hline Area & 0.31 & 0.34 & 0.25 & 0.12 & 0.52 & 0.29 \\
\hline Population & 1.28 & 0.57 & 3.20 & 0.45 & 1.97 & 0.45 \\
\hline GDP & 1.30 & 0.54 & 1.49 & 0.23 & 2.09 & 0.55 \\
\hline Urban Extent & 1.02 & 0.61 & 1.94 & 0.39 & 1.71 & 0.33 \\
\hline Ag. Extent & 0.39 & 0.33 & 1.15 & 0.04 & 0.83 & 0.11 \\
\hline \multirow[t]{2}{*}{ Wetlands } & 1.86 & 1.35 & 3.32 & 1.11 & 2.67 & 1.59 \\
\hline & \multicolumn{6}{|c|}{ 5M SLR } \\
\hline Area & 1.21 & 1.24 & 0.63 & 0.48 & 2.30 & 1.65 \\
\hline Population & 5.57 & 2.69 & 7.49 & 2.38 & 8.63 & 3.02 \\
\hline GDP & 6.05 & 2.38 & 3.91 & 1.42 & 10.2 & 2.85 \\
\hline Urban Extent & 4.68 & 3.03 & 4.94 & 2.24 & 8.99 & 2.72 \\
\hline Ag. Extent & 2.10 & 1.76 & 3.23 & 0.38 & 4.19 & 1.16 \\
\hline Wetlands & 7.30 & 6.57 & 7.09 & 4.70 & 9.57 & 7.94 \\
\hline
\end{tabular}




\section{Historical Development of Off-land Structures}

The development of off-land structures is not a new concept for the world. Early applications of floating structures take the form of floating boat bridges over rivers that date back to antiquity. Figure. 3 shows About 480 BC, King Xerxes of Persia led his army across the Hellespont, now called the Dardanelles, using two rows of floating bridges, each consisting of about 300 boats laid side by side. [7]. Such kind of floating bridges were mainly built as a necessity of war, permitting the movement permitting the movement of soldiers and equipment between ground bases and marine vessels during that period. Later on many bridges were constructed on this concept of tying the boats \& ships. Other than the bridges there are many examples of very old floating villages throughout history. They have appeared in different parts of the world due to various needs and reasons.

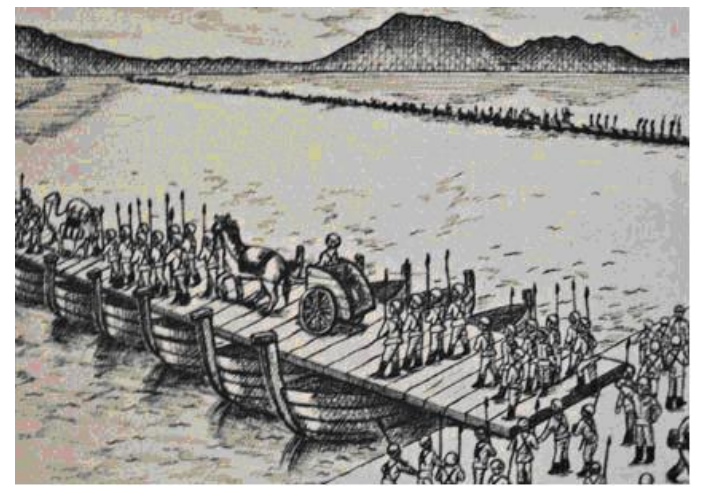

Figure 3. The floating boat bridge by King Xerxes of Persia (Source: Hammond and Roseman, 1996)

Figure 4 shows in the sixteenth or seventeenth century, Ganvie's floating city (Sometimes called the Venice of Africa) was established by the Tofinu people, as a protective measure from Dahomeys which was a slave trading tribe that dominated the region during the time. [8] Other than this example, Vietnam, Indonesia. Thailand. China. Peru and Bolivia also have a history of floating villages. There are many countries which have floating habitation not for permanent living but for the tourism purpose, like In India, boat houses in Kerala and Kashmir are important attraction of tourists.

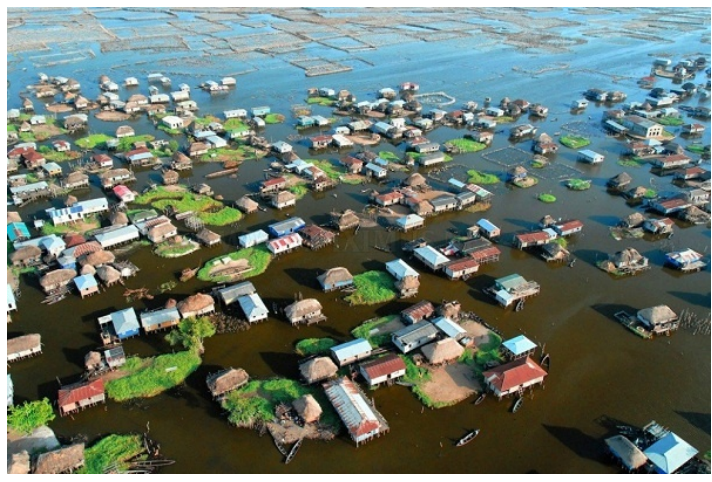

Figure 4. Ganvie's floating city, Africa (Source: www.afritorial.com)
In our contemporary history use of floating structures other than bridges, primarily starts after industrial revolution. Original concept of floating habitation begins by the primitive man who built small boats as a means of navigation. Later on, as man started progressing he built bigger boats, which were used to cross the sea. It took him several days, months. He had to stay on these boats and this gave rise to the concept of boat houses [9]. With the development in construction and technology men designed huge ships (cruises) as warships and as a mode of transport that can accommodate more than thousands of people.

Numerous proposals have been made for very large floating structures. Proposed applications ranges from the visionary floating city to more likely floating airport, military bases, wave power generators and deep ocean mining platforms. Till now, most of the off land buildings and structures have been developed for oil exploration and tourism only but due to future scenario these all are going to become a need with mix of technological advancement. Advancement in term of technologies can be of construction, development of new materials, energy generation system, security and control system.

\section{Scope of Off-land Structures}

The scope of neighborhood sized, self-sustained independent 'off land' floating structure can be decided on basis of the criteria of land use systems of different categories like agriculture and industries should be promoted to be used on ground. These kinds of manufacturing and production based structures have heavy concentrated load and don't need to be used in luxurious way, so we need to reduce maintenance, operational and transportation cost related to production. The purpose to build the 'off land' structure is to provide an isolated, peaceful and efficient environment for working and living. For this kind of structure, preferably residential, office, institutional, academic, commercial or recreational buildings are needed to be developed as single or mixed use form. For example, IT parks with all basic amenities and residential features for its employees can be developed in the form of floating structures. Residential townships can be developed to cater the requirements of farm houses, beach houses, \& bungalows. This kind of specific block will be self-sustained in itself.

Academic buildings like colleges and universities can also be developed in form of off land structure. This category required bigger area in peaceful environment so these kinds of structures can be accommodated in such urban pockets. Jails and prisons can be design in such structures in isolated forms from main town. In such case it will be very easy to handle safety and security based issues. Yoga and Meditation centers also need isolated and peaceful environment, so these structures can be designed here in form of floating structures. Entertainment facilities \& utility plants are also one of the important categories of buildings which can be designed in floating form. Emergency rescue 
bases in floating form can be developed in earthquake prone areas like Japan, (sea sided earthquake prone countries) and in flood prone areas. These off land structures ought to be designed as net zero energy buildings as well as with net zero carbon foot print and self-sustained in terms of energy by using renewable energy resources to make it environmentally favorable. Economically-the development cost will be very high so it will target a specific category higher income group.

\section{Case Studies}

There are various off land structures have been constructed and few are under construction in the form of floating structure. Few prominent examples have been summarized as below:

\subsection{Green Star, Maldives}

A floating hotel and conference center named as Greenstar has been designed by Water Studio, Netherlands (Figure 5) in Maldives (a nation widely considered to be on the front lines of global warming because of its sea level). The Greenstar, contains 800 rooms and a Conference Center for up to 2000 participants. The Greenstar will blend-in naturally with the existing surrounding islands. The green covered star-shape building symbolizes Maldivians innovative route to conquer climate change. This will become the next location for conferences about climate change, water management and sustainability. A unique Floating Restaurant Island will be built next to it [10].

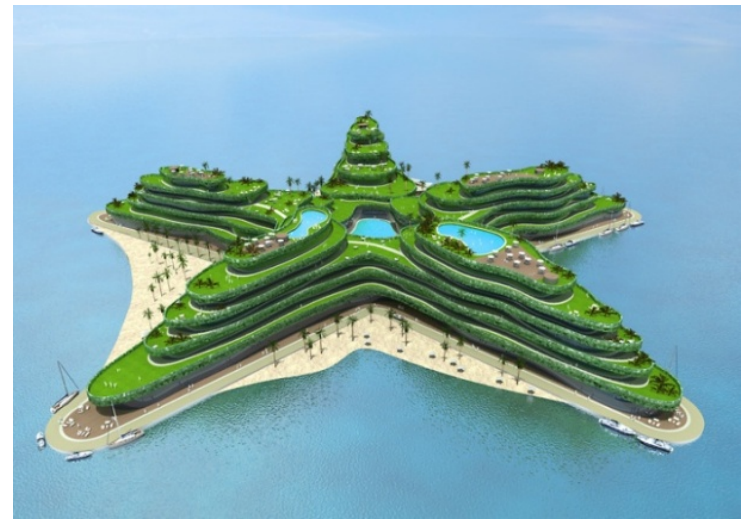

Figure 5. The Greenstar, floating hotel and conference center, Maldives (Source: www.waterstudio.nl)

\subsection{Floating golf course, Maldives}

Another important floating structure going to be developed in Maldives is the world's first floating golf course. Threatened with rising sea levels from climate change, the island nation may be doomed to a watery grave unless it transitions to floating developments. Developed by Dutch Docklands and designed through a collaboration between golf course developer Troon Golf and
Waterstudio.NL, the zero-footprint solar-powered golf course will be one of the first floating developments and is expected to bring in a wave of new tourists.it is also designed to minimize its impact on the surrounding ecosystem. The artificial floating islands will incorporate technologies such as water cooling, water desalination, and the use of floating solar blanket fields. Underwater tunnels will connect the holes and facilities together, while allowing golfers to experience the reef. [11].

\subsection{Lily Pad - The Floating Ecopolis}

In 2008 a conceptual model of The Floating Ecopolis (Figure 6a \& Figure 6b), known as the Lilypad, was designed by Belgian architect Vincent Callebaut. He says, "A true Amphibian, half aquatic and half terrestrial city, able to accommodate 50,000 inhabitants and inviting biodiversity". Callebaut imagines his structure at 250 times the scale of a lilypad, with a skin made of polyester fibres coated in titanium dioxide which would react with ultraviolet light and absorb atmospheric pollution.

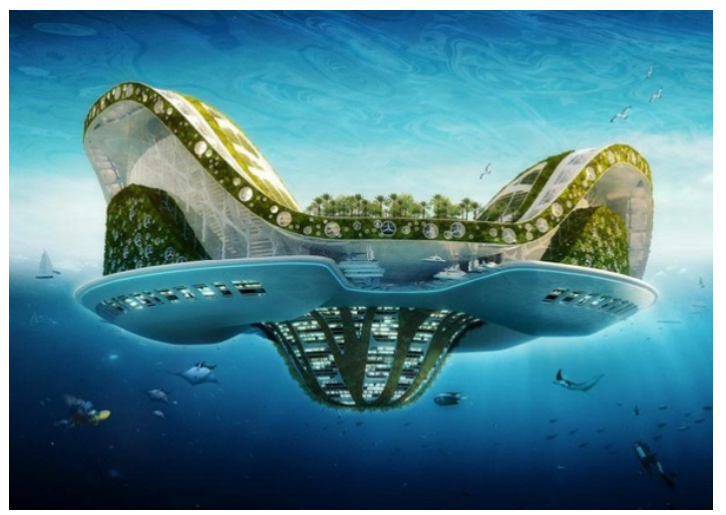

Figure 6(a). The Lilypad (Source: Vincentcallebaut architectures)

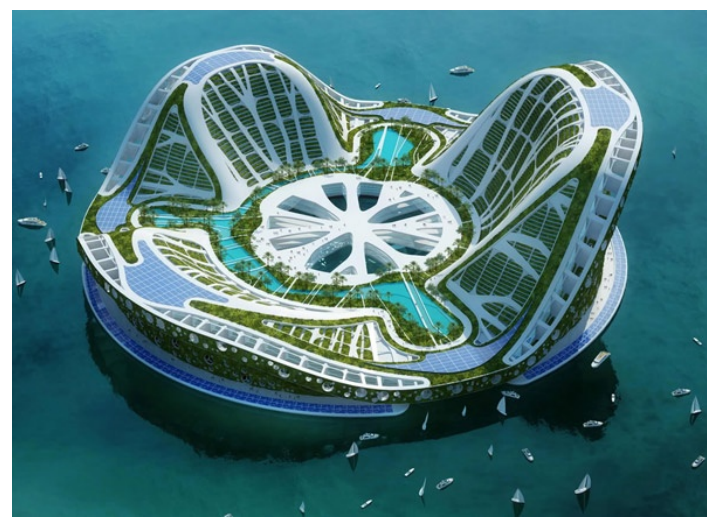

Figure 6(b). The Bird's eye view of Lilypad ((Source: Vincentcallebaut architectures)

The Lilypad comprises of three marinas and three mountain regions with streets and structures strewn with foliage. "The goal is to create a harmonious coexistence of humans and nature," said Callebaut. With a central fresh water lagoon acting as ballast, the whole construction would be carbon neutral utilizing solar, thermal, wind, hydraulic, 
tidal and osmotic energies. With high density populations living in low-lying areas -- The Netherlands, Polynesia, Bangladesh -- the Ecopolis, its creator believes, could be the answer to mass human displacement that global warming is predicted to cause [12].

\section{Design Methods for Off Land Structures}

The major issue for designing such off-land structures is related to transportation and connectivity. In case of transportation, huge energy is consumed. So, design of such mega floating structure should be in such a manner to minimize the horizontal travelling distance. A clustered form of planning in the form of vertical towers can be good for decreasing the transportation distances. This condition will be defined by concentrated load bearing condition of these structures. There should be proper means to have access to boat, ship, submarine \& helicopter. Another important issue will be energy production and consumption by these off-land structures. The most important renewable sources for onsite energy production for sustainable off land structure are solar, wind and hydroelectric energy. Using onsite renewable energy, these off land structures may play an important role in reducing our carbon footprint.

At site level condition, a breakwater (usually needed if the significant wave height is greater than $4 \mathrm{~m}$ as a thumb rule) is needed for reducing wave forces impacting the floating structure (Figure 7). This breakwater will be formed by a ring of columns around the structure with the option to bear the turbines to generate the electricity due to movement of waves [13]. The mooring system (Figure 8) must be well designed so that it can ensure the stability of very large floating structure to keep it in position so that the facilities installed on the floating structure can be reliably operated and to prevent the structure from drifting away under critical sea conditions and storms.

A freely drifting very large floating structure may lead to damage not only the surrounding facilities but also the loss of human life if it collides with ships. Note that there are a number of mooring systems such as the dolphin-guide frame system, mooring by cable and chain, tension leg method and pier/quay wall method (Figure 8). Another feature could be the design of the edges of the structure. By proper choice of edge layout, the propagation of the incident waves into the main part of the structure can be reduced by efficient scattering or reflection of the incident waves on the weather side [13]

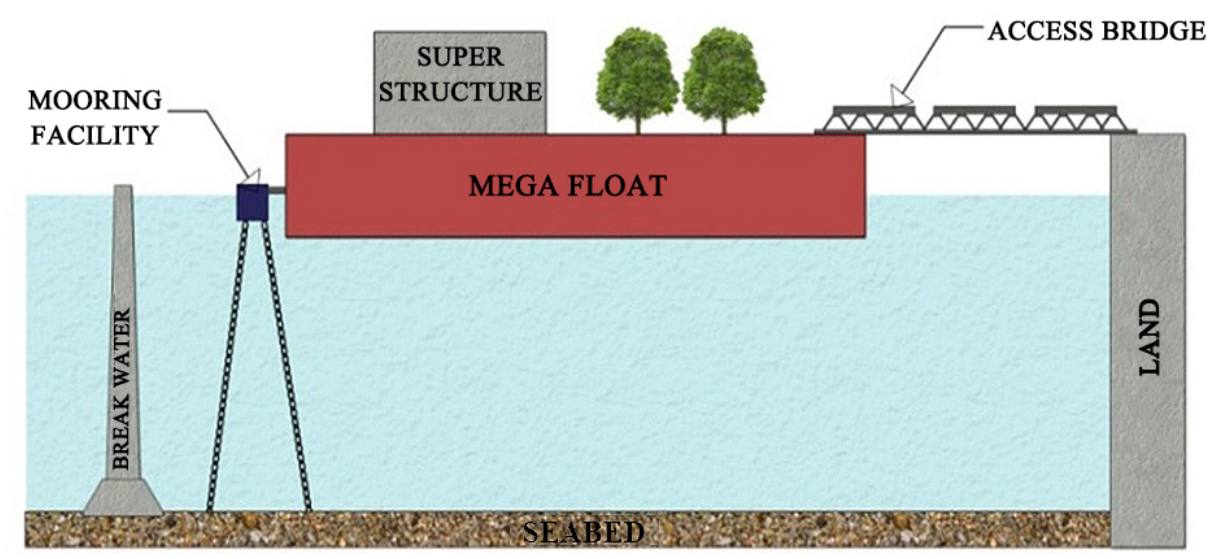

Figure 7. Components of off land structures

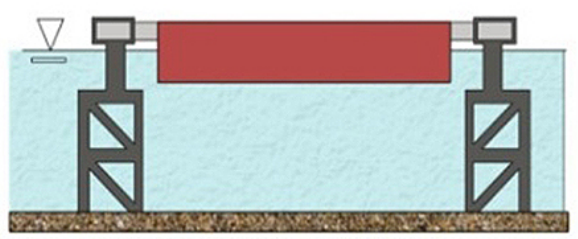

DOLPHIN-FRAME GUIDE METHOD

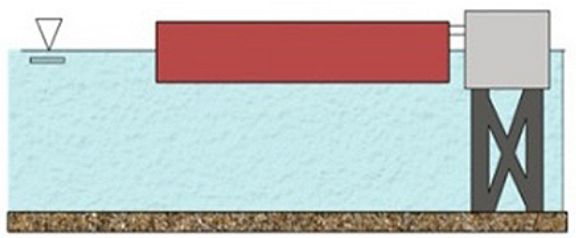

PIER / QUAY WALL METHOD

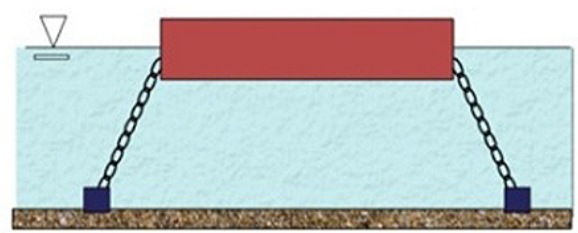

CHAIN / CABLE METHOD

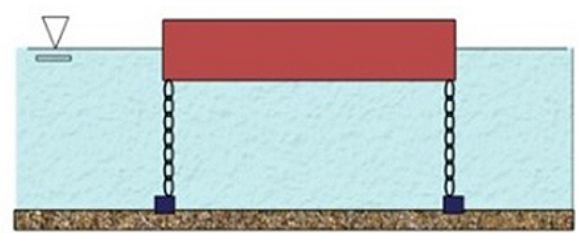

TENSION LEG METHOD

Figure 8. Different types of mooring systems. 
The materials to be used for the floating body may be steel, or concrete or steel-concrete composite and the relevant specifications have to be followed for the main structure. This concrete will be in category of special water tight, light weight concrete to increase water tightness of structure and to decrease overall density by reducing its dead load. In case of the buildings of the structures we will use recyclable material having lesser energy consumption according to their life cycle assessment, to make such structure environment friendly [13].

\section{Design Considerations for Off Land Structures}

Adequate performance of off-shore structures has to be ensured by designing them to comply with serviceability and safety requirements for a service life of 100 years or more. Serviceability criteria are introduced to ensure that the structure should fulfill the function required to perform as, and are specified by the standards, owner and user. Major serviceability requirements are related to performance during movement of waves. An important design issue regarding safety of personnel is evacuation and rescue. An effective safety measure related to this can be to provide a safe place where people can survive or board after an accident. In principle the global failure modes of floating structures include capsizing, sinking, structural failure and drift-off. For such condition we have to design the installed blocks on main floating surface as they should also be floating type independently in itself. This will be a safety measure if there is any disaster due to any reason if main structure tends to submerge in water then these structures will start flowing independently. Planning wise it can be designed in form of radial planning form with a control center \& main building as a nucleus. Other buildings can be planned in a concentric ring from to be placed as per decreasing priority form center to periphery.

Technically there will be some other considerable load based factor in design of floating structures such as abnormal loads like impact loads due to collision of ships with the floating structure, effects of earthquakes including dynamic water pressure, effects of temperature change, effects of water current, effects of tidal change, effects of seabed movement, snow load, effects of tsunamis, effects of storm surges, ship waves, seaquake, brake load, erection load, effects of drift ice and ice pressure, effects of drifting bodies, effects of marine growths etc. These mega-floats will be protected from seismic shocks since they will be inherently base isolated. They will not suffer from differential settlement due to reclaimed soil consolidation. As these urban pockets will also be very high in cost so they will have higher surface coverage and Floor Area Ration (FAR) as per load bearing capacity \& available resources around the pockets.

\section{Conclusions}

In this paper there has been an attempt to study the possibilities of off-land structures on water. It discusses the need of floating structures and their scope of contribution towards development and growth of urban centers. A critical appraisal of the development and different design methods of off land floating structures has also been done. The off land structures or mega-floats have advantages over the traditional land reclamation solution for space creation in many ways like they will be cost effective in case of large water depth. It should be noted that the cost of imported sand for land reclamation in some countries has risen significantly and it may come a time that sand may not be even available from neighboring countries [14]. Floating structures may be environmental friendly as they will not damage the marine eco-system, or silt-up deep harbors or disrupt the tidal/ocean currents, they will be easy and fast to construct (components may be prefabricated at different shipyards and then brought to the site for assembling) and therefore sea-space can be speedily exploited. Psychologically the structures will be very efficient due to peaceful and clean environment.

\section{REFERENCES}

[1] United Nations (2011). United Nations Department of Economic and Social Affairs, Population Division, New York: United Nations, Online available from http://www.un.org/en/development/desa/population/publicati ons/pdf/popfacts/PopFacts_2011-2.pdf

[2] U.S. Geological Survey. How much water is there on, in, and above the Earth? Online available from http://water.usgs.gov/edu/earthhowmuch.html

[3] Igor, S. World fresh water resources. in: Peter H. Gleick, eds. 1993, Water in Crisis: A Guide to the World's Fresh Water Resources. New York: Oxford University Press

[4] Gregory, J. (2013). Projections of sea level rise.In:ipcc(Intergovernmental panel on Climate change), ed. Climate Change 2013: The Physical Science Basis. Cambridge:Cambridge University Press.ch.13. Online available from http://www.climatechange2013.org

[5] Bora, K. (2013). Global Warming Effect: Sea level may rise more than 2 Meters In Future by Each Degree of warming, International Business Times, 16 July, 2013. Online available from

http://www.ibtimes.com/global-warming-effect-sea-level-ma y-rise-more-2-meters-future-each-degree-warming-1346971

[6] Dasgupta, S. et al. (2007). The Impact of Sea Level Rise on Developing Countries: A Comparative Analysis, The Policy Research Working Paper Series, WPS4136. Online available from

https://openknowledge.worldbank.org/bitstream/handle/1098 6/7174/wps4136.pdf

[7] Hammond, N. and Roseman, L. (1996). The Construction of Xerxes' Bridge over the Hellespont, The Journal of Hellenic Studies, Vol. 116, pp. 88-107. 
[8] Afritorial.(2012). Africa's Venice: The city lake of Ganvie, Online available from http://afritorial.com/africa-venice-thecity-lake-of-ganvie

[9] Nguyen, L. (2012). An Overview of Ha Long Bay's Fishing Villages. WMF Journal. Online available from http://www.wmf.org/journal/overview-ha-long-bay $\%$ E2\%80 $\% 99$ s-fishing-villages.

[10] Waterstudio.(2014). Greenstar, Floating Hotel and Conference Center, Maldives. Online available from http://waterstudio.nl/projects/72

[11] Waterstudio.(2014). Floating Golfcourse, Maldives. Online available from http://waterstudio.nl/projects/66
[12] Knight, M. (2008). The Floating Ecopolis. cnn. Online available from- http://edition.cnn.com/2008/TECH/science/0 7/10/lilypads/index.html?iref=mpstoryview

[13] Watanabe. E, et al. (2004). Very large floating structures: Applications, Analysis and Design. Centre for Offshore Research and Engineering. National University of Singapore. Singapore, Online available from http://www.eng.nus.edu.sg/core/Report\%20200402.pdf

[14] Gillibrand, J. (2007). Floating and Modular Infrastructure: Strengthening Private Sector Participation and Investment in Physical Infrastructure, Asian Development Bank Institute. Tokyo, Online available from http://www.adbi.org/files/2007.11.19.cpp.panel.member.3.jo hn.gillibrand_ports.floating.infrastructure.pdf 